\title{
It's not just poverty: unregulated global market and bad governance explain unceasing deforestation in Western Madagascar
}

\author{
Ghislain Vieilledent*,1,2,3,4 , Marie Nourtier ${ }^{5}$, Clovis Grinand ${ }^{5}$, \\ Miguel Pedrono ${ }^{6}$, Alison Clausen ${ }^{7}$, Tsiky Rabetrano $^{7}$, \\ Jean-Roger Rakotoarijaona ${ }^{8}$, Bruno Rakotoarivelo ${ }^{8}$, Fety A. Rakotomalala ${ }^{5}$, \\ Linjanantenaina Rakotomalala ${ }^{9}$, Andriamandimbisoa Razafimpahanana ${ }^{7}$, \\ José M. Ralison ${ }^{10}$, and Frédéric Achard ${ }^{4}$
}

[1] CIRAD, UPR AMAP, F-34398 Montpellier, FRANCE

[2] Univ Montpellier, AMAP, CIRAD, Montpellier, FRANCE

[3] CIRAD, UPR Forêts et Sociétés, F-34398 Montpellier, FRANCE

[4] JRC European Commission, Bio-economy unit, I-21027 Ispra (VA), ITALY

[5] Nitidæ, F-34090 Montpellier, FRANCE

[6] CIRAD, UMR ASTRE, F-34398 Montpellier, FRANCE

[7] Wildlife Conservation Society, 101 Antananarivo, MADAGASCAR

[8] Office National de l'Environnement, 101 Antananarivo, MADAGASCAR

[9] ESSA-Forêts, 101 Antananarivo, MADAGASCAR

[10] Biotope, 101 Antananarivo, MADAGASCAR

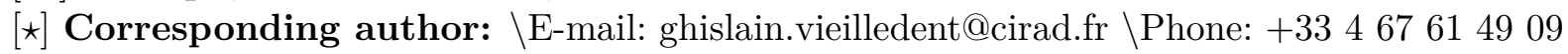




\section{Abstract}

Madagascar is recognized both for its unparalleled biodiversity and the high level of threat suffered by this biodiversity, associated in particular with anthropogenic deforestation. Despite sustained efforts to fight poverty and curb deforestation, forest cover in Madagascar is rapidly decreasing. To try to explain why it is so difficult to stop deforestation in Madagascar, we analysed the recent deforestation process in Western Madagascar through satellite image analysis and field surveys. We show that deforestation has increased from less than $0.9 \% / \mathrm{yr}$ on 2000-2010 to more than 2\%/yr on 2010-2017. We identified two major causes of deforestation, which were not associated with subsistence agriculture: slash-and-burn agriculture for the cultivation of cash crops (maize and peanut), and uncontrolled fires to create open pasture. Maize production is mainly at the destination of the domestic market and is used in particular for livestock feeding. Peanut production has boomed since 2013 and more than half of it is now exported towards asiatic countries. The money earned by farmers is principally invested into zebu herd acquisition. Trade of agricultural commodities benefits several intermediaries, some of whom have political responsibilities thus creating conflicts of interest. On the other hand, agents from institutions in charge of the management of the protected areas have no means to enforce laws against deforestation. In the absence of an efficient strategy to stop deforestation, we predicted that $38-93 \%$ of the forest present in 2000 will have disappeared in 2050. Forest loss, apart from biodiversity loss and climate-change global issues, will be at the expense of local population. In order to stop deforestation, international aid should be used to improve local governance to enforce environmental laws and pressure should be put on trading companies to buy certified agricultural commodities that are not derived from deforestation.

Keywords: biodiversity, conservation, conflict of interest, cyclones, dry deciduous forest, fires, illegal logging, Madagascar, protected areas, slash-and-burn agriculture, tropical deforestation. 


\section{Introduction}

Tropical forests provide important ecosystem services at the global scale, such as biodiversity conservation and climate regulation (Costanza et al., 1997), and at the local scale for peoples' livelihoods (Anderson et al., 2006; Jeannoda et al., 2007; Gardner \& Davies, 2014). On the island of Madagascar, three types of tropical forests, covering about $15 \%$ of the country area, can be found: the moist forest in the East, the xerophytic forest in the South, and the dry forest in the West (Humbert, 1955). Among all the ecosystem services they provide, Malagasy forests are particularly important for the unique biodiversity they shelter, both in terms of species diversity and endemism in many taxonomic groups (Goodman \& Benstead, 2005; Brooks et al., 2006).

However, a large part of the original tropical forest is thought to have disappeared since the arrival of the humans on the island around 2000 years ago (Green \& Sussman, 1990; Harper et al., 2007; Vieilledent et al., 2018b), some studies suggesting that $90 \%$ of the island was originally covered by forest (Burns et al., 2016). From 1953 to 2014, a loss of about 46\% of the forest cover has been estimated (Vieilledent et al., 2018b), leading to an estimated extinction of $9 \%$ of the species between 1950 and 2000 in Madagascar (Allnutt et al., 2008). The common narrative attributes deforestation to the extreme poverty of the country and subsistence farming through slash-and-burn agriculture (Jarosz, 1993; Scales, 2011; Gardner et al., 2013). In 2010, about $81 \%$ of the population lived below the international poverty line of $\$ 1.25$ per day. In 2015 , more than $70 \%$ of the 24 million population of Madagascar (United Nations, 2017) rely heavily on forests for their livelihood (Anderson et al., 2006). Moreover, the Malagasy population is rapidly increasing, with population growing at a rate close to $3 \% / \mathrm{yr}$, resulting in a doubling each 25 years.

To curb deforestation, several conservation and rural development programs have been implemented in Madagascar since the establishment of the first protected areas in 1927. The Madagascar Protected Area System (SAPM) has seen both an increase in the number of protected areas and an increase in the place taken by rural development programs to accompany conservation actions (Virah-Sawmy et al., 2014). Rural development programs aimed at alleviating poverty, increasing agriculture productivity, and supporting education, health and local governance in the periphery of the protected areas (Freudenberger, 2010). Since 2003, Madagascar's protected area coverage expanded from 1.7 to 6.4 Mha (11\% of the country area, see Kremen et al. (2008) and Corson (2014)). In parallel with the development of the SAPM, the REDD+ (Reducing Emissions from Deforestation and Forest Degradation) mechanism have emerged in Madagascar to avoid deforestation combining conservation and development actions (Ebeling \& Yasue, 2008). Five REDD+ pilot projects have been initiated in Madagascar since 2004 over a total of 1.76 Mha of forest (Demaze, 2014).

All of these actions were funded by the donor community, with some limited revenues from tourism entry fees to national parks. Donor efforts were led by the World Bank and USAID (United States Agency for International Development) (Freudenberger, 2010). The Malagasy Government does not contribute financially to the management of the protected area network. The total funding of the National Environmental Action Program (NEAP) from 1990 to 2010 was estimated at approximately $\$ 450$ million for environment activities, with another $50 \%$ 
for related development programs (e.g. agriculture and health interventions) (Freudenberger, 2010). Other bilateral donors (mainly Europe, France and Germany) have also funded specific socio-environmental projects (\$102 million in the period 2005-2011) (Critical Ecosystem Partnership Fund, 2014). The main international NGOs (World Wide Fund for Nature, Conservation International, Wildlife Conservation Society) and international research centers (such as CIRAD and IRD French research centers) also contributed significantly to the financial effort by securing alternative resources to support conservation and development programs (Critical Ecosystem Partnership Fund, 2014). Regarding REDD+ activities, the private sector also provided substantial funding. Air France supported the first phase of the PHCF REDD+ project (2008-2012) with \$5 million and the Makira REDD+ project managed by the Wildlife Conservation Society made close to $\$ 3$ million in sales between 2013 and 2018. Annually, this represents a rough estimate of about $\$ 60$ million per year from the donor community to fund environmental and related development activities in Madagascar $(80 \%$ of the annual national budget for the environment sector) (Critical Ecosystem Partnership Fund, 2014).

Despite all the efforts and money invested in conservation and development programs over the past 30 years (1985-2015), deforestation has not stopped on the island. Out of the 10.8 Mha of tropical forest in 1990, around 1.5 Mha (13\% of the forest) was deforested during the period 1990-2010 (Harper et al., 2007; Vieilledent et al., 2018b), which corresponds to an average annual deforestation rate of 75,000 ha/yr (0.72\%/yr). More worryingly, Madagascar has seen an acceleration of the deforestation recently (Vieilledent et al., 2018b). Madagascar was the third country in the world with the fastest acceleration of tree cover loss $(+8.3 \%$ of deforested area per year) in the period 2001-2014 (see Hansen et al. (2013) and http://ow.ly/RBbgw). In the period 2010-2015, deforestation reached an average rate of 110,000 ha/yr (1.2\%/yr). Forest cover in 2015 has been estimated at 8.8 Mha (Vieilledent et al., 2018b,a). The conclusion is unfortunately rather clear: conservation and development programs since the mid 1980s have failed to save Madagascar's forests. It is therefore legitimate to wonder why such initiatives have not been successful and what could be alternative solutions to stop deforestation. Also, the recent deforestation might be attributable to new factors, independent of local human activities, such as global climate change, cyclone and natural fires, which would imply the need for conservation measures different to the ones used in the past.

To try to answer these questions, we undertook an in-depth analysis of the deforestation process in three study areas in Western Madagascar. The study areas were located around three protected areas: the Menabe-Antimena New Protected Area (acronym MANAP in French), the Kirindy-Mite National Park (KMNP), and the Mikea National Park (MIKEA). These three protected areas are characteristic of dry deciduous forest in Madagascar which is home to a unique floral and faunal biodiversity (Fig. 1). Many species are endemic to the region such as the symbolic Adansonia grandidieri of the Avenue of the Baobabs or Microcebus berthae, the smallest species of primate in the world. We derived historical forest cover change maps at $30 \mathrm{~m}$ resolution for the three study areas for the periods 1990-2000-2010-2017. We validated these maps with field observations. To identify the main causes of the deforestation, we conducted local household and environmental stakeholder surveys. A much clearer scheme emerged from this analysis explaining why environmental actions are currently failing to stop deforestation. Finally, based on a spatial deforestation model, we predicted the likely 
bioRxiv preprint doi: https://doi.org/10.1101/2020.07.30.229104; this version posted July 31, 2020. The copyright holder for this preprint (which

was not certified by peer review) is the author/funder, who has granted bioRxiv a license to display the preprint in perpetuity. It is made available under aCC-BY 4.0 International license.

future of the tropical dry forest in 2050 in the three study areas in the absence of any efficient solution to curb deforestation. 


\section{Materials and Methods}

\subsection{Historical deforestation maps}

We used $30 \mathrm{~m}$ resolution cloud-free forest cover maps available for Madagascar for the years 1990, 2000, 2010, and 2017 (Vieilledent et al., 2018b,a). These maps were obtained combining the 1990 and 2000 forest cover maps by Harper et al. (2007) and the 2000-2017 tree cover loss data by Hansen et al. (2013). We used these national forest cover maps to derive forest cover change maps for the periods 1990-2000, 2000-2010, and 2010-2017 for our three study areas around the Menabe-Antimena New Protected Area (E: 44.20934, W: 44.81850, S: -20.36440, N: -19.55838, in decimal degrees), the Kirindy-Mite National Park (E: 43.67555, W: 44.35049, S: -21.38515, N: -20.50082), and the Mikea National Park (E: 43.11582, W: 44.17152, S: -22.98611, N: -21.62237).

For each period and each study area, we computed the mean annual deforested area (in ha/yr), and the mean annual deforestation rate $\theta$ (in $\% / y r$ ) using the forest cover estimates $F_{1}$ and $F_{2}$ at dates $t_{1}$ and $t_{2}$ and the following formula (Puyravaud, 2003; Vieilledent et al., 2013): $\theta=1-\left(1-\left(F_{1}-F_{2}\right) / F_{1}\right)^{(1 / T)}$, with $T=t_{2}-t_{1}$ (in yr).

Field work was conducted during two weeks in March and June 2016 to verify the presence of the recent (2000-2010-2015) patches of deforestation in the three study areas. We validated the deforestation maps on these periods and identified the main causes of deforestation in the three study areas.

\subsection{Deforestation model}

Following Vieilledent et al. (2013), we considered two processes for modelling deforestation, a first one describing the intensity of deforestation (number of hectares of forest deforested each year) and a second one describing the location of the deforestation (spatial probability of deforestation). For the intensity of deforestation, we used two historical means at the study area level considering a conservative scenario (S1) and a worst-case scenario (S2). The conservative scenario assumed a lower deforestation rate corresponding to the mean annual deforestation observed in the period 2000-2010. The worst-case scenario assumed a higher deforestation rate corresponding to the mean annual deforestation observed in the period 2010-2017, during which the deforestation has dramatically increased.

For the location of the deforestation, we used a map of the spatial probability of deforestation at $30 \mathrm{~m}$ resolution for the year 2010 for Madagascar. The map is freely available at https:/bioscenemada.cirad.fr/forestmaps. We used this national map for our three study areas (Appendix 1). The map was derived from a Binomial logistic regression model of deforestation where the observed deforestation at the pixel level in the period 2000-2010 was explained by several environmental spatial variables. Altitude, distance to forest edge, distance to main town, distance to main road, protected areas, and distance to past deforestation (period 1990-2000) were used as explanatory variables. These variables describe the accessibility, the land policy and the historical deforestation. The model also included spatial random effects at the regional scale $(10 \times 10 \mathrm{~km}$ grid cells $)$ to account for the residual variability 
in the deforestation process which is not explained by the environmental variables (see https://ghislainv.github.io/forestatrisk for more details on model specifications).

To forecast the forest cover in 2050 for our three study areas, we removed the 2010 forest pixels with the highest probability of deforestation following the annual deforestation rate of the two intensity scenarios considered (conservative scenario S1 and worst-case scenario S2). As a rough validation of our projections, we computed the percentage of observed deforestation in the period 2010-2017 included in the predicted deforestation in the period 2010-2050.

\subsection{Surveys}

During two weeks in March and June 2016, we conducted surveys among local farmers and environmental stakeholders (Tab. 1) in the three study areas. The objectives of the surveys were firstly to identify the causes of the deforestation and secondly to assess the efficiency of the conservation actions implemented by the organisations in charge of the management of the protected areas, either the NGO Fanamby for MANAP or the parastatal association Madagascar National Parks for KMNP and MIKEA. Surveys were qualitative and included non-directive questions (no "yes-or-no" questions). Discussing with the "Fokontany" chief at Lambokely, we also obtained rough population estimates on the period 2010-2015 for the two villages of Kirindy and Lambokely. The "Fokontany" is a Malagasy administrative unit under the level of the township. Information from field surveys was cross-checked and complemented by a review of technical reports on the maize and peanut sectors in Madagascar (Youssi, 2008; Ministère de l'Agriculture, de l'Elevage et de la Pêche de Madagascar, 2004; Chan Mouie, 2016; Fauroux, 2000) and scientific studies on the deforestation process in south-east Madagascar (Scales, 2011; Zinner et al., 2014; Fauroux, 2000; Réau, 2002; Casse et al., 2004; Gardner et al., 2013). We also used the FAOSTAT website (http://www.fao.org/faostat) to obtain information on the national production of maize and peanut; and the UN Comtrade website (https://comtrade.un.org) to obtain information on the exportations. 


\section{Results}

\subsection{Intensity and pattern of deforestation}

Deforestation rates have continuously increased since 1990 for the MANAP and KMNP study areas (Tab. 2). After a decrease in 2000-2010, deforestation in the MIKEA study area has dramatically increased in 2010-2017 (Tab. 2). We estimated that 5429 ha, 4312 ha and 8210 ha of forest have disappeared annually in the period 2010-2017 in the MANAP, KMNP, and MIKEA study areas, respectively. This corresponds to annual deforestation rates of 2.16-4.31\%/yr. Deforestation has more than doubled in the period 2010-2017 compared to the period 2000-2010, for which deforestation was estimated at $0.66-0.87 \% / \mathrm{yr}$.

In the MANAP study area, large patches of deforestation associated with slash-and-burn agriculture were identified around the Kirindy and Lambokely villages and to the south of Belo-sur-Tsiribihina town (Fig. 2a, label A).

In the KMNP study area, mosaic deforestation associated with slash-and-burn agriculture occurred outside the protected area, showing the relative effectiveness of the protected area to prevent deforestation in the short term (Fig. 2b, label A). Much larger patches of deforestation have been observed on the two periods 2005-2010 and 2010-2015 in the east part of the protected area (Fig. 2b, label B). These large patches of deforestation have been caused by the cyclone Fanele that occurred in January 2009 (Appendix 2) and which was followed by uncontrolled fires. Dispersed and small-scale deforestation has also been observed in the northern and western parts of the park associated with illegal logging activities (Fig. 2b, label C).

In the MIKEA study area, most of the deforestation was located in the north of the protected area (far from the Madagascar National Park office, which is located in the south of the study area) and was both due to slash and burn agriculture (Fig. 2c, label A) and to uncontrolled fires following cyclone Haruna which occurred in February 2013 (Fig. 2c, label B; and Appendix 2).

\subsection{Deforestation drivers}

\subsubsection{Proximate causes of deforestation: slash-and-burn agriculture and uncon- trolled fires}

In the MANAP study area, the main cause of deforestation was the slash-and-burn agriculture (locally known as "hatsake") for maize (Zea mays L.) and peanut (Arachis hypogaea L.) crop (Fig. 3). The burning of forests allows expansion of cultivable areas and optimisation of labour productivity. It provides nutrient rich ash and light for crops, increasing yields and reducing the necessary time for weeding. In the KMNP and MIKEA study areas, slash-and-burn agriculture was also identified as a cause of deforestation, but preferentially outside protected areas (Fig. 2b-c, label A).

Inside the KMNP and MIKEA protected areas, uncontrolled fires (Fig. 3) were the main cause of deforestation (Fig. 2b-c, label B). People repeatedly set fire to former grasslands (called "bozake") outside the protected area to obtain a flush of green pasture for their livestock. 
When uncontrolled, fires can spread across large areas of forest and cross the boundaries of the protected area. In 2009, the cyclone named Fanele (Appendix 2) impacted a large area of the forest in the Kirindy-Mitea National Park leaving a lot of wood fuel on the ground. This allowed uncontrolled fires to spread throughout large areas of the park in the years following the cyclone (Fig. 2b, label B). These fires were eventually stopped with water and sand by the agents of the park with the help of local villagers. The same thing happened in the MIKEA study area after cyclone Haruna in 2013 (Fig. 2c, label B and Appendix 2). Cyclones provide opportunities for local people to gain land on the forest. Following cyclones, it is more difficult to accuse people of destroying the forest and cyclones allow farmers to avoid the labour-intensive work of cutting down the trees before burning.

Illegal logging was also identified as a cause of forest degradation in the three study areas (Fig. 2b, label C). Illegal logging is not a direct cause of deforestation but a forest without precious wood is more easily burnt than an intact forest, and so degradation usually precedes deforestation. Timber (Fig. 3) is mainly used for house and boat construction and sold in local markets in Belo-sur-Mer and Morondava towns.

\subsubsection{Ultimate causes of deforestation}

\subsubsection{Demographic growth and migration}

The population of Kirindy and Lambokely villages (Fig. 2a) has been roughly multiplied by 5 between 2010 and 2015 (from about 600 to 3000 inhabitants for Kirindy and from about 1000 to 5000 for Lambokely). This increase was due both to demographic growth and migration. The demographic growth rate in Madagascar is close to $3 \% / \mathrm{yr}$ (Vieilledent et al., 2013) which means that the population doubles every 25 years on average. In Lambokely and Kirindy villages, the families we surveyed had all more than six children. Also, the possibility of cropping cash crops have attracted many people from the south of Madagascar during the last years, in particular from the Androy and Atsimo-Atsinanana regions (South-East of Madagascar). First migrants arrived in the central Menabe to work in large agricultural concessions authorized by the French colonial government. Notably, many Tandroy migrants have arrived in the 1960s and established near the Beroboka village (located between Kirindy and Lambokely villages) to work in the sisal (Agave sisalana Perr.) plantation of the de Heaulme family which is now abandoned. Consecutive droughts and crop failure in SouthEastern Madagascar resulted in severe famines there, that forced several thousand Tandroy families to migrate to Western Madagascar in search for new farming land. Population increase in Western Madagascar has accentuated the pressures on forests.

\subsubsection{Cash crops and unregulated market}

In the study areas we surveyed, peanuts (Fig. 3) was cultivated as a cash crop. Peanuts are consumed as whole seeds or transformed into peanut oil (Ministère de l'Agriculture, de l'Elevage et de la Pêche de Madagascar, 2004). According to FAOSTAT data (Tab. 3), the area harvested for peanut crop in Madagascar has increased of 50\% in 7 years, from 52,000 ha in 2010 to 78,426 ha in 2017. At the same time, according to UN Comtrade data, peanut exports have also dramatically increased, from 1,233 T in 2010 to 27,370 T in 2017 (Tab. 3 
and Appendix 3). In 2017, about half of the national peanut production was exported, mainly at the destination of the Asian market (Vietnam and Pakistan, in particular). During our stay in the field in June 2016, which took place in the middle of the peanut harvest, we observed an uninterrupted parade of trucks arriving empty in the villages of Lambokely and Kirindy (Fig. 2a) and leaving loaded with peanut bags.

Our surveys indicated that maize (Fig. 3) was cultivated for auto-consumption (about $30 \%$ of the production) and as a cash crop (70\%). FAOSTAT and UN Comtrade data indicate that only a small part of the national maize production was exported (about 5,000 T/yr out of a total production of about 200,000 T/yr), most part of the production being at the destination of the domestic market (Tab. 3 and Appendix 3). Several people we interviewed said that the maize production was sold to the Star company to brew the THB national beer. We computed that about 2,471 ha of maize are necessary to produce the annual volume of THB of $840,000 \mathrm{hL}$ (Appendix 4). This is a relatively small area compared to the 249,186 ha of maize harvested annually in Madagascar (Tab. 3). Other sources (Ministère de l'Agriculture, de l'Elevage et de la Pêche de Madagascar, 2004) indicated that maize is used for livestock (poultry and pigs) feeding in Madagascar.

Farmers we interviewed sold the peanuts and maize at the price of 1,400 MGA (Madagascar Ariary) and 400 MGA per kilogram, respectively. For 2016, the production for a household was approximately of $1.6 \mathrm{~T}$ of peanut and $2.5 \mathrm{~T}$ of maize, thus providing an annual income of about 3.24 millions MGA. Farmers we interviewed said they invested the money earned from the sale of the maize and peanut harvest in zebu herd acquisition.

\subsubsection{Limits in the application of conservation policy}

Since 1987 forest clearance has been illegal in Madagascar (Décret n87-143, 20 April 1987), even outside the protected areas.

However, as underlined by NGO in charge of the protected area management, the law is not respected nor applied. Almost nobody is prosecuted for forest clearance. Small farmers can be prosecuted as examples but are rarely incarcerated. Large landholders or those inciting small farmers to clear the forest are not prosecuted. During our stay in the field, seven people were arrested for doing slash-and-burn agriculture but were released a few days later. The political crisis of 2009, followed by several years of political instability during which funding for protected area management was severely curtailed, has reinforced this state of lawlessness.

Several people we interviewed said that officials in the army or with political responsibilities, who are at the same time businessmen or entrepreneurs, are involved in this trade.

Moreover, authorities commonly have economic interests in not curbing deforestation as they are often involved in the trade associated with cash crops. Indeed, many politicians in Madagascar are also business leaders. Throughout the country, the Government has delegated management of the protected areas to external parties such as Fanamby and Madagascar National Parks. However, the structures in charge of the management of the protected areas have no legal enforcement powers. These powers are retained by the Malagasy Government which does not have the resources or the will to implement them adequately. Thus, the role 
of protected area managers is limited to raising awareness about forest conservation issues, inventorying and monitoring the biodiversity in the parks, and organizing community and NGO patrols to discourage forest clearance or report offences. They do not have the right to arrest people or to draw up a report and decide on a fine. NGOs also engage local people as conservation partners (in some cases named "polis ny ala") to try to make them stewards of their forest but these have practically no power and social pressures mean that they are often unwilling to report illegal acts committed by neighbours or relatives.

\subsection{Projected deforestation}

Following the conservative scenario S1 (projecting 2000-2010 mean annual deforestation) and the worst-case scenario S2 (projecting 2010-2017 mean annual deforestation), we predicted that $38-93 \%$ of the forest present in 2000 will have disappeared in 2050 (Tab. 4). In the period 2000-2017, around 25\% of the forest has already disappeared. Forest in 2050 should remain predominantly in the protected areas but deforestation is not expected to stop at the boundaries of the parks (Fig. 4). The model predicted that deforestation in the future should occur close to places were deforestation occurred in the past, thus correctly simulating the contagious process of deforestation (Fig. 4). Deforestation is also more likely to occur at short distances to villages and roads and at the forest edge (Fig. 4). Forest fragmentation is also predicted to increase in association with deforestation (higher number of disconnected forest patches in Fig. 4). Most of the deforestation observed in the period 2010-2017 was included in the deforested area predicted by the model in the period 2010-2050 (47-100\% for MANAP, 56-100\% for KMNP, and 43-88\% for MIKEA for scenarios S1 and S2, respectively), thus validating partly the predictions regarding the location of the future deforestation. 


\section{Discussion}

\subsection{Historical deforestation, projections and consequences on livelihoods, biodiversity and climate-change}

For the three study areas, we have shown a strong increase of the annual deforestation rates on the period 1990-2015. This increase, also observed by Scales (2011) and Zinner et al. (2014) in the region, clearly demonstrate the inefficiency of the recent environmental policies to reduce deforestation. In the absence of any efficient future policy to curb deforestation, we predicted a 36-59\% forest loss on the period 2000-2050. This scenario, confirmed by the results of Zinner et al. (2014), would be terrible for both local villagers in terms of livelihoods and at the global scale for biodiversity and carbon emissions. In term of loss of biodiversity, Allnutt et al. (2008) estimated a 9\% decrease in the number of species after a deforestation of $40 \%$ on the period 1950-2000. In our case, given a forest loss of 36-67\%, we can assume that the biodiversity loss would be of the same order of magnitude on the period 2000-2050. Many species endemic to the region, such as Hypogeomis antimena, Mungotictis decemlineata, Microcebus berthae and Pyxis planicauda could experience a dramatic demise of their populations resulting in a rapid tailspin toward extinction. Dry forests sequester an average of $52 \mathrm{Mg} / \mathrm{ha}\left(1 \mathrm{Mg}=10^{6} \mathrm{~g}\right)$ (Vieilledent et al., 2016). Considering the predicted forest cover loss of 229,384-393,119 ha on the period 2010-2050 for the three study areas combined, deforestation would lead to emissions of $11.9-20.4 \mathrm{Tg}\left(1 \mathrm{Tg}=10^{12} \mathrm{~g}\right)$ of carbon in the atmosphere, thus contributing significantly to climate change.

\subsection{Deforestation is not associated directly to poverty but to un- regulated market and bad governance}

Our field observations and surveys indicated that a large part of the deforestation was attributable to slash-and-burn agriculture for cash crops (maize and peanut). The major part of the maize and peanut production is at the destination of the domestic market.

Increase in area harvested for peanut crop is clearly associated to an increase in peanut exports toward the Asian market.

While a large part of the maize production in Western Madagascar have been exported through the ports of Morondava and Tulear during the successive maize booms in the 20th century (Scales, 2011; Fauroux, 2000), the production of maize seems to be presently mainly at the destination of the domestic market.

Area harvested for maize crop are relatively constant since 2000, and slightly decreasing since 2010 .

In particular, maize is used for livestock feeding. The annual household income we computed associated to the selling of cash crops (about 3.24 millions MGA) was relatively high compared to the estimated median household income of 2.02 millions MGA (Gallup World Poll from the Gallup Organization). With the money earned from the sale of the maize and peanut harvest, farmers invest in accumulating zebu herd (Casse et al., 2004; Réau, 2002). Buying zebu herd is a way for farmers of saving money such as a bank would do it (Réau, 2002). 
In Madagascar, cattle also represent status, wealth, and cultural identity (Hobbs, 2016). In Western Madagascar, people's diet is mainly composed of manioc (Manihot esculenta (Crantz)), wild and cultivated yams (Dioscorea spp.), and maize (Falola \& Jean-Jacques, 2015). The main purpose of the slash-and-burn agriculture is thus not to obtain food for subsistence but to cultivate cash crop in order to invest in livestock acquisition and to secure new farming lands (Fauroux, 2000). In line with other studies (Grandin et al., 1988; Jarosz, 1993; Scales, 2011; Gardner et al., 2013), we underline that it would be over simplistic to reduce the causes of the deforestation to the poverty of local population.

Of course, Malagasy farmers do not make large profits and do not harvest most of the benefits associated to the culture of maize and peanut. Many intermediaries, such as storers, domestic transporters, resellers, exporters and corrupt officials reap most of the profits. Foreign entrepreneurs (European and Chinese) as well as entrepreneurs from the Malagasy elite (including "Karana", the descendants of Indo-Pakistani migrants) connect rural households to the domestic market. Field surveys reported that several officials in the army or with political responsibilities, who are at the same time businessmen or entrepreneurs, are involved in this trade. As a consequence, stopping deforestation would go against the economic interest of some people having decisional and political power in Madagascar. In previous studies, Jarosz (1993) and Scales (2011) have clearly shown how economic booms of agricultural commodities and policies have driven deforestation in Madagascar during French colonization. Nowadays, deforestation in central Menabe is driven by the increasing demand in maize and peanut on the domestic market and by the possibility of making economic profits in these sectors.

Slash-and-burn agriculture for cash crops and the economic profits are made possible by the non-application of the environmental law in Madagascar. Forest clearance is illegal in Madagascar since 1987 (Décret n87-143, 20 April 1987). In the field, the agents of MNP and Fanamby have no legal enforcement powers to arrest offender even when apprehended. Under-resourced local Government agencies that retain such legal powers are generally corrupt and have a low technical capacity, making their actions virtually ineffective. As a consequence, illegal activities such as slash-and-burn agriculture or setting fire to open pastures continue in full sight of everyone. This situation has been accentuated by the political crisis of 2009-2012 in Madagascar (Ploch \& Cook, 2012). Madagascar is a fragile State country (the Fund for Peace, 2016). Common characteristics of a fragile State include a central Government so weak or ineffective that it has little practical control over much of its territory. Our study confirms that the deforestation problem in Madagascar is more a governance problem in a context of unregulated economy than an economic development problem. Interestingly, two global studies have recently shown that corruption (Venter et al., 2016), overexploitation and agriculture (including crop farming and livestock farming) (Maxwell et al., 2016) were responsible for a major part of the biodiversity loss, thus reflecting our results.

\subsection{Enforcing law and controlling agricultural sector to stop de- forestation in Western Madagascar}

If we want to stop deforestation in western Madagascar, it seems necessary to rethink the conservation strategies we adopted during the last 30 years, which was based on extended the 
protected area network and alleviating poverty. One solution we see would be that national companies engage into ecological certification for agriculture commodities in Madagascar (Laurance et al., 2010; Kiker \& Putz, 1997). Relative to estimates of conservation costs in the developing world, it has been shown that existing levels of environmental aid are insufficient (Miller et al., 2013). If the amount of the environmental aid have to be increased, the targets have also to be redefined and improving governance in Madagascar should be considered a priority (Smith et al., 2003). Brazil, which have reduced by two third the Amazon deforestation on 2005-2011 compared to 1996-2005, is a good example to show that both law enforcement (enforcement of the Brazilian Forest code) and control of the agricultural sector (voluntary moratoriums by the soy bean and beef industries) are efficient ways to rapidly curb deforestation (Boucher et al., 2013; Nepstad et al., 2009). This success, even if temporary, should inspire conservationists working in Madagascar and in other developing countries facing tropical deforestation in general.

Following the recent election of Andry Rajoelina as president of Madagascar, several researchers and conservationists have recently propose solutions to takle the decline in the rule of law in Madagascar (Jones et al., 2019). Among the solutions they propose, they suggest in particular to Tackle environmental crime and Invest in Madagascar's Protected Areas. Out study demonstrates that... 


\section{Acknowledgements}

This study took form in the framework of the BioSceneMada project (https://bioscenemada. cirad.fr) and the Roadless forests project (https://forobs.jrc.ec.europa.eu/roadless). The BioSceneMada project was funded by FRB (Fondation pour la Recherche sur la Biodiversité) and the FFEM (Fond Français pour l'Environnement Mondial) under the project agreement AAP-SCEN-2013 I. The Roadless forests project was funded by the European Commission. We thank all the people who welcomed us and kindly provided us with useful information during our field trip, both institutional people (from DREF, MNP, WWF and Fanamby) and villagers. The authors declare no conflict of interest.

\section{Data availability statement}

All the data and codes used for this study are made available publicly in the menabe repository on the GitHub platform at the following web address: https://github.com/ghislainv/menabe. git. The results and the manuscript are fully reproducible running the $R$ script menabe.R from the menabe git repository. 


\section{Tables}

Table 1: List of surveys conducted among local farmers and environmental stakeholders. Surveys were conducted around the Menabe-Antimena New Protected Area, the Kirindy-Mite National Park, and the Mikea National Park. The "Fokontany" is a Malagasy term defining an administrative territory under the level of the township. In Madagascar, the management of the protected areas is under the responsibility of Madagascar National Parks (MNP) or delegated to another environmental Non-Governmental Organisation (such as Fanamby for Menabe-Antimena New Protected Area).

\begin{tabular}{|c|c|c|c|c|c|}
\hline Id & Category & Name & Institution & Position & Date \\
\hline 1 & National Parks & M. Toany & MNP & $\begin{array}{l}\text { Director of the Mikea } \\
\text { National Park }\end{array}$ & $15 / 03 / 16$ \\
\hline 2 & Migrant and farmer & Farmer 4 & Basibasy commune & $\begin{array}{l}\text { Member of the Mikea } \\
\text { community }\end{array}$ & $16 / 03 / 16$ \\
\hline 3 & Migrant and farmer & Farmers 5 and 6 & $\begin{array}{l}\text { Antanimieva } \\
\text { commune }\end{array}$ & Chiefs of family & $17 / 03 / 16$ \\
\hline 4 & Migrant and farmer & Farmers 7 and 8 & $\begin{array}{l}\text { Ankantsakantsa } \\
\text { commune }\end{array}$ & Chiefs of family & $18 / 03 / 16$ \\
\hline 5 & Administration & Mayor & $\begin{array}{l}\text { Analamisampy } \\
\text { commune }\end{array}$ & Mayor & $19 / 03 / 16$ \\
\hline 6 & Private Enterprise & Technicians & $\begin{array}{l}\text { Ankililoaka } \\
\text { commune }\end{array}$ & $\begin{array}{l}\text { Agriculture and sales } \\
\text { technicians }\end{array}$ & $20 / 03 / 16$ \\
\hline 7 & National Parks & $\begin{array}{l}\text { Mamy Rakotobe- } \\
\text { nandrasana }\end{array}$ & $\mathrm{MNP}$ & $\begin{array}{l}\text { Director of the } \\
\text { conservation program for } \\
\text { KMNP }\end{array}$ & $07 / 06 / 16$ \\
\hline 8 & $\begin{array}{l}\text { Environmental } \\
\text { NGO }\end{array}$ & Roland Eve & WWF & $\begin{array}{l}\text { Landscape Planning and } \\
\text { Management advisor for } \\
\text { KMNP }\end{array}$ & $08 / 06 / 16$ \\
\hline 9 & $\begin{array}{l}\text { Government } \\
\text { representative }\end{array}$ & Mme Cynthia & DREF Menabe & $\begin{array}{l}\text { Acting director of the } \\
\text { Direction Régionale des } \\
\text { Eaux et Forêt }\end{array}$ & 09/06/16 \\
\hline 10 & Woman & Woman 1 & Kirindy village & $\begin{array}{l}\text { Woman of farmer living in } \\
\text { the Kirindy village }\end{array}$ & $10 / 06 / 16$ \\
\hline 11 & $\begin{array}{l}\text { Migrants and } \\
\text { farmers }\end{array}$ & Farmers 2 and 3 & Lambokely & $\begin{array}{l}\text { Two family chiefs with } \\
\text { women and children }\end{array}$ & $10 / 06 / 16$ \\
\hline 12 & Administration & Chief 1 & Lambokely & Fokontany chief & $10 / 06 / 16$ \\
\hline 13 & $\begin{array}{l}\text { Environmental } \\
\text { NGO }\end{array}$ & Tahina Riniavo & Fanamby & $\begin{array}{l}\text { Director of the } \\
\text { conservation program for } \\
\text { MANAP }\end{array}$ & $10 / 06 / 16$ \\
\hline 14 & Migrant and farmer & Farmer 1 & Kiri & $\begin{array}{l}\text { Chief of a family with a } \\
\text { woman and eight children }\end{array}$ & $10 / 06 / 16$ \\
\hline
\end{tabular}


Table 2: Change in annual deforestation with time. MANAP: Menabe-Antimena New Protected Area, KMNP: Kirindy-Mite National Park, MIKEA: Mikea National Park. D90-00, D00-10, and D10-17: annual deforestation (in ha/yr) for the periods 1990-2000, 2000-2010, and 2010-2017 respectively, followed by the annual deforestation rate in parenthesis (in \%/yr). The annual deforestation has more than doubled on the period 2010-2017 compared to the period 2000-2010.

\begin{tabular}{lrrr}
\hline Site & D90-00 & D00-10 & D10-17 \\
\hline MANAP & $1,042(0.64 \%)$ & $1,312(0.87 \%)$ & $5,429(4.31 \%)$ \\
KMNP & $874(0.44 \%)$ & $1,606(0.85 \%)$ & $4,312(2.60 \%)$ \\
MIKEA & $3,934(0.87 \%)$ & $2,793(0.66 \%)$ & $8,210(2.16 \%)$ \\
\hline
\end{tabular}

Table 3: National statistics for maize and peanut production and exports. The area harvested is in hectares (ha), the yield is in tonne per ha per year ( $\mathrm{T} / \mathrm{ha} / \mathrm{yr}$ ), the total production and the exportation are in tonnes per year $(\mathrm{T} / \mathrm{yr})$. Sources: FAOSTAT (http://www.fao.org/faostat) for production and UN Comtrade (https://comtrade.un.org) for exports.

\begin{tabular}{lrrrrr}
\hline Crop & Year & Area & Yield & Production & Exports \\
\hline Maize & 2000 & 192,135 & 0.9 & 169,800 & 5,458 \\
& 2005 & 252,838 & 1.5 & 391,000 & 13 \\
& 2010 & 264,429 & 1.6 & 411,914 & 1,572 \\
& 2015 & 194,269 & 1.7 & 329,367 & 4,458 \\
& 2017 & 162,176 & 1.7 & 281,000 & 652 \\
Peanut & 2000 & 47,205 & 0.7 & 35,030 & 1,077 \\
& 2005 & 54,506 & 0.7 & 38,053 & 659 \\
& 2010 & 52,000 & 0.6 & 30,000 & 1,233 \\
& 2015 & 66,591 & 0.9 & 58,483 & 17,716 \\
& 2017 & 78,426 & 0.7 & 55,646 & 27,370 \\
\hline
\end{tabular}


Table 4: Change in forest cover with time. MANAP: Menabe-Antimena New Protected Area, KMNP: Kirindy-Mite National Park, MIKEA: Mikea National Park. Area: land area (in ha). F2000, F2010 and F2017: forest area (in ha) for the years 2000, 2010 and 2017, respectively. F2050: projected forest area (in ha) for the year 2050. About 25\% of the forest have disappeared on the period 2000-2017 in the three sites and we predict the loss of 38-93\% of the forest on the period 2000-2050 for the three sites assuming a conservative scenario S1 (projecting the 2000-2010 annual deforestation) or a worst-case scenario S2 (projecting the 2010-2017 annual deforestation), respectively.

\begin{tabular}{lrrrrrrr}
\hline Site & Area & F1990 & F2000 & F2010 & F2017 & F2050,S1 & F2050,S2 \\
\hline MANAP & 349,360 & 166,648 & 156,224 & 143,108 & 105,109 & 90,644 & 0 \\
KMNP & 403,080 & 203,920 & 195,175 & 179,117 & 148,932 & 114,887 & 6,637 \\
MIKEA & $1,208,910$ & 472,542 & 433,199 & 405,274 & 347,804 & 293,575 & 76,878 \\
\hline
\end{tabular}




\section{Figures}

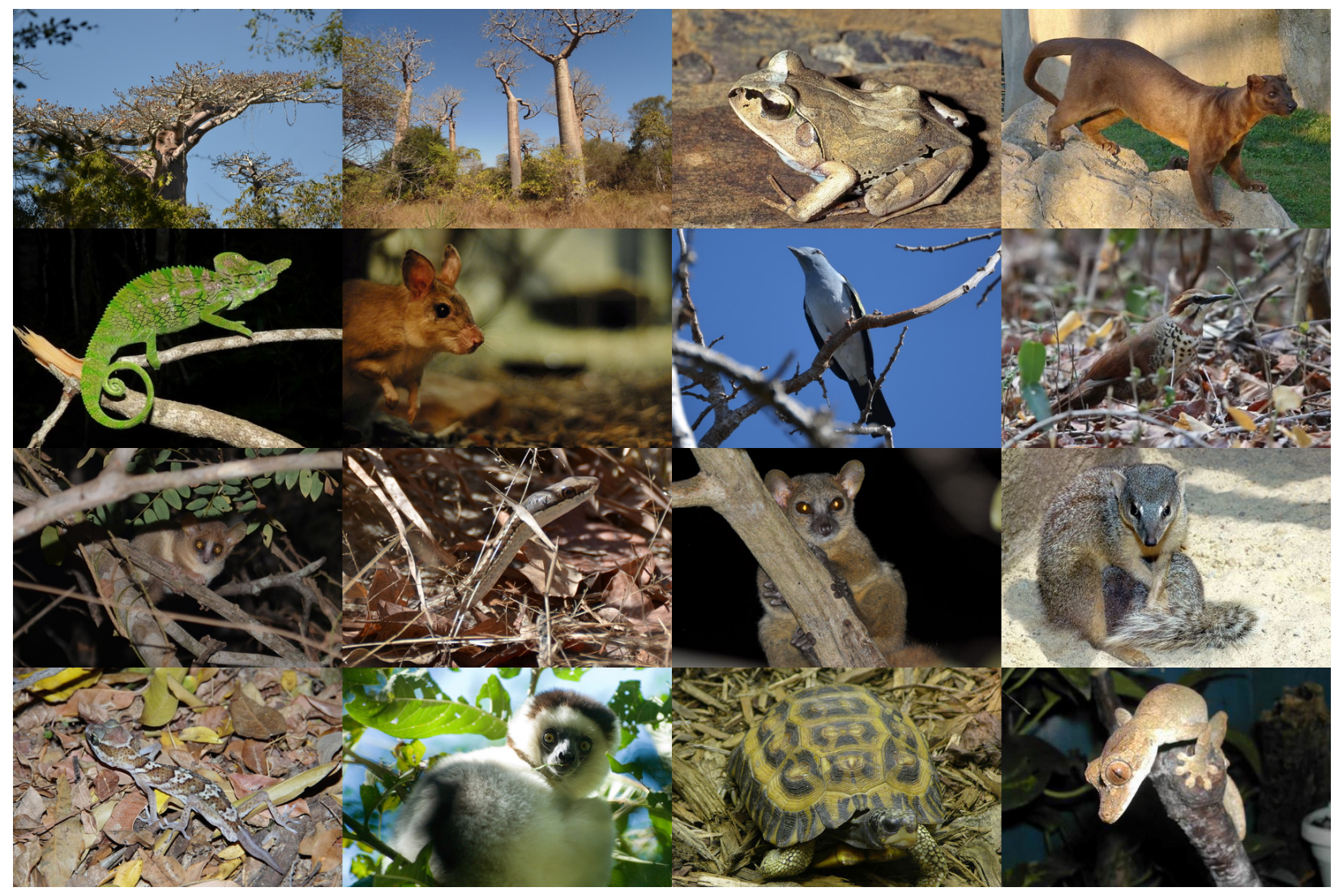

Figure 1: Emblematic species representative of the biodiversity in Western Madagascar. The dry forest of Western Madagascar is home to a very large number of species, many of which being endemic to the region. We present here some examples of this biodiversity for different taxonomic groups: Plants, Birds, Mammals (including Lemurs), Amphibians and Reptiles. From top-left to bottom-right: 1. Adansonia grandidieri (Baillon, 1888), 2. Adansonia rubrostipa (Jumelle \& Perrier, 1909), 3. Aglyptodactylus laticeps (Glaw, Vences \& Böhme, 1998) 4. Cryptoprocta ferox (Bennett, 1833), 5. Furcifer labordi (Grandidier, 1872), 6. Hypogeomis antimena (Grandidier, 1869), 7. Leptosomus discolor (Hermann, 1783), 8. Mesitornis variegata (Geoffroy Saint-Hilaire, 1838), 9. Microcebus berthae (Rasoloarison, Goodman \& Ganzhorn, 2000), 10. Mimophis mahafaliensis, 11. Mirza coquereli (Grandidier, 1867), 12. Mungotictis decemlineata (Grandidier, 1867), 13. Paroedura picta (Peters, 1854), 14. Propithecus verreauxi (Grandidier, 1867), 15. Pyxis planicauda (Grandidier, 1867), 16. Uroplatus guentheri (Mocquard, 1908). Credits: 1,2,5,7,9,10,13,15: authors; 3: Miguel Vences; 11: Louise Jasper; 4,6,8,12,14,16: Wikipedia. 

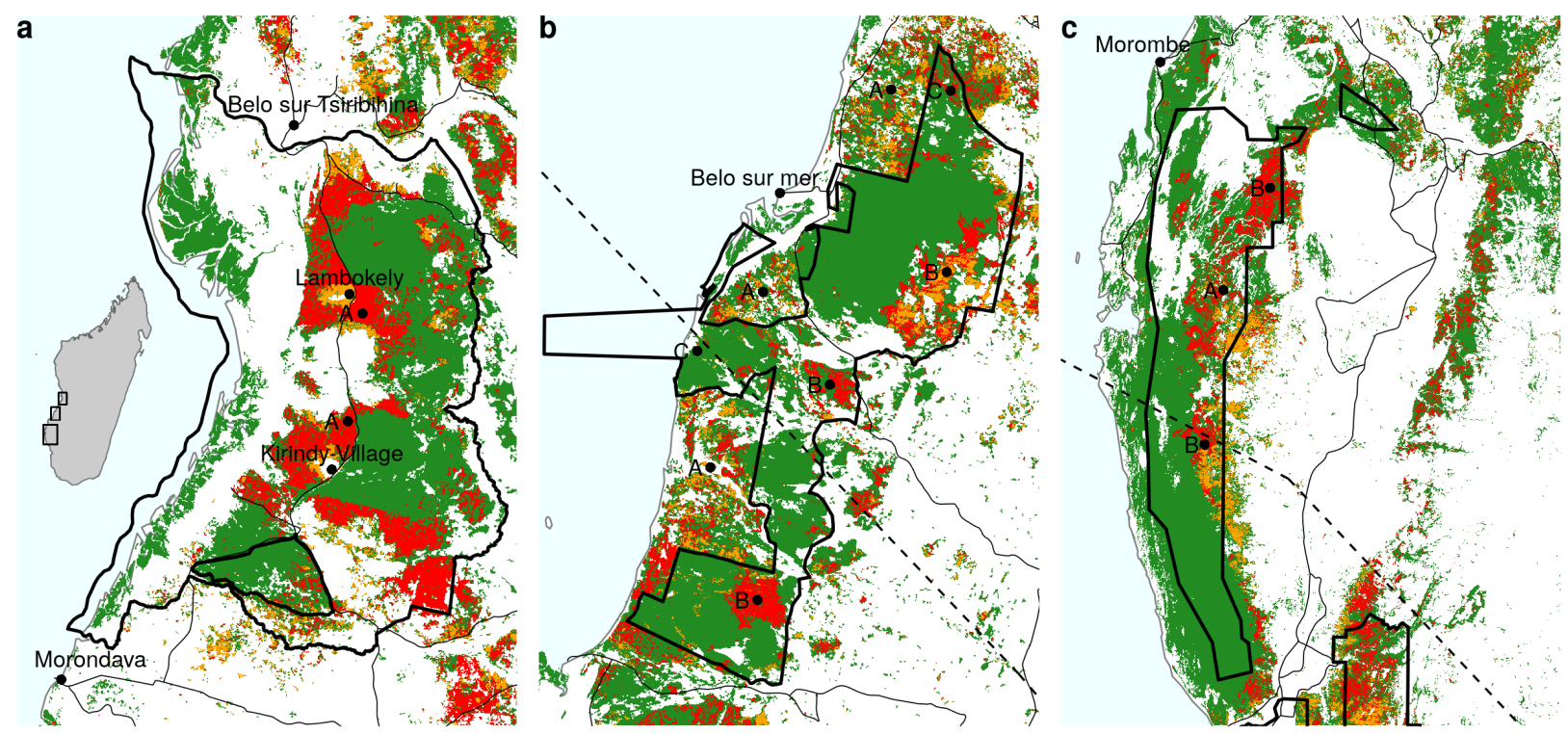

Figure 2: Historical deforestation on the period 2000-2010-2017 in the three study areas. Madagascar map is represented on the left panel (a), with MANAP study area at the north, KMNP study area in the middle, and MIKEA study area at the south (black rectangles). On each of the panels, the boundaries of the protected areas are represented with black polygones (source: Rebioma, http://rebioma.net). Main roads are represented with thin black lines (source: FTM BD500). Coast line is represented with a thin grey line. Morondava and Belo-sur-Tsiribihina are the main cities located near MANAP. Belo-sur-Mer is the main village located near KMNP. Morombe is the main village located near MIKEA. The dashed lines on b) and c) show the trajectories of the cyclones "Fanele" (January 2009) and "Haruna" (February 2013), respectively (source: JTWC, https://www.metoc.navy.mil/jtwc). Green: forest cover in 2017, orange: 2000-2010 deforestation, red: 2010-2017 deforestation (Vieilledent et al., 2018a). In the study areas, the main causes of deforestation are: (A) slash-and-burn agriculture ("hatsake") for maize and peanut crops, (B) cyclones followed by uncontrolled fires, and (C) illegal logging. 


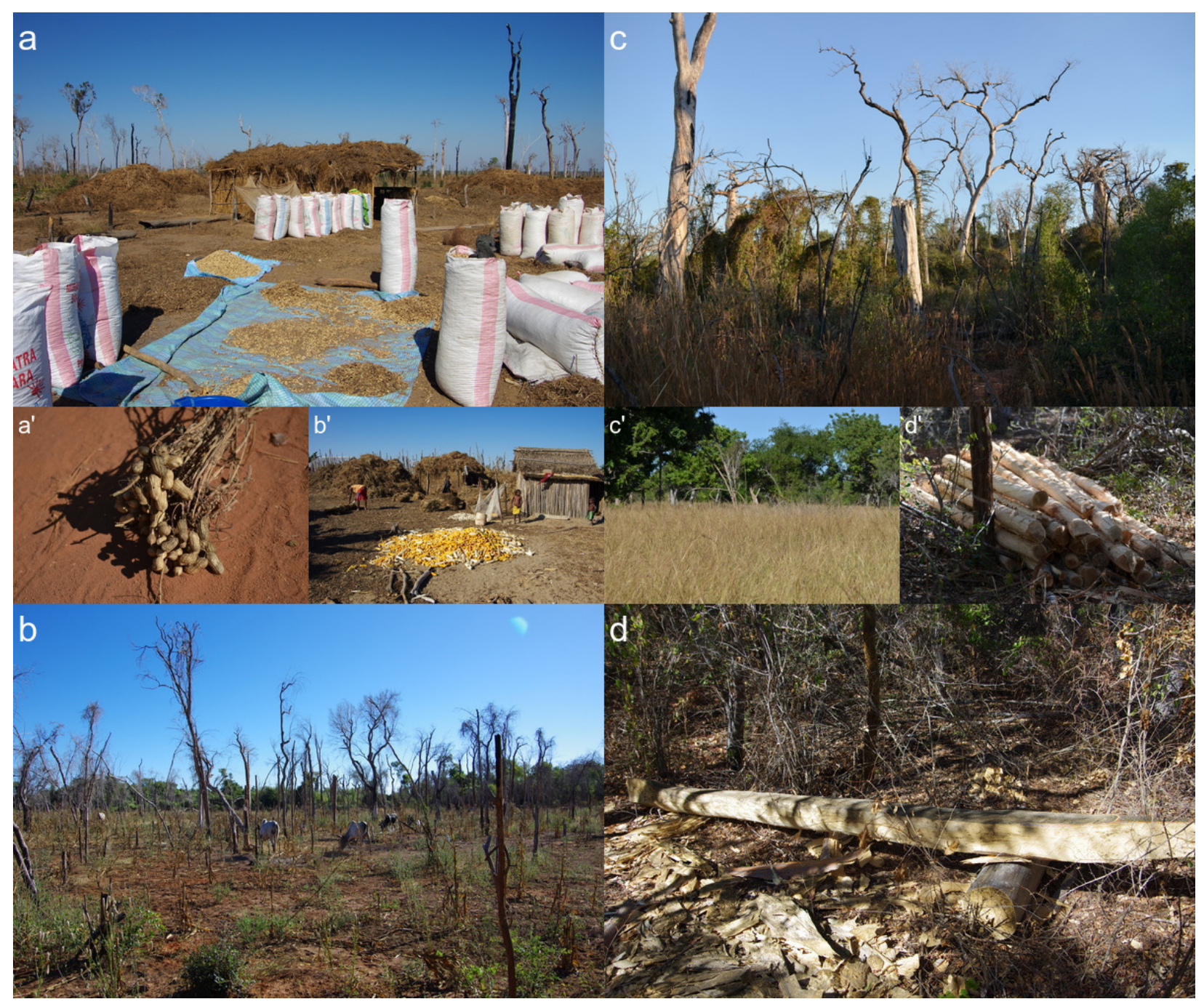

Figure 3: Main causes of deforestation in Western Madagascar. a-a': Slash-and-burn agriculture ("hatsake") for peanut crop. Peanut (a') is cultivated as a cash crop. Most of the production is at the destination of the domestic market. b-b': Slash-and-burn agriculture for maize crop. Maize (b') is cultivated for auto-consumption and as a cash crop. The production of maize is at the destination of the domestic market and is used in particular for livestock feeding. c-c': Cyclone followed by uncontrolled fires. Cyclone "Fanele" (2009) caused tree mortality and accumulation of wood fuel on the ground. As a consequence, uncontrolled fires set on nearby pastures (c') spread over large areas of forest after 2009. d-d': Illegal logging. Timbers are used for house and dugout canoe construction. 

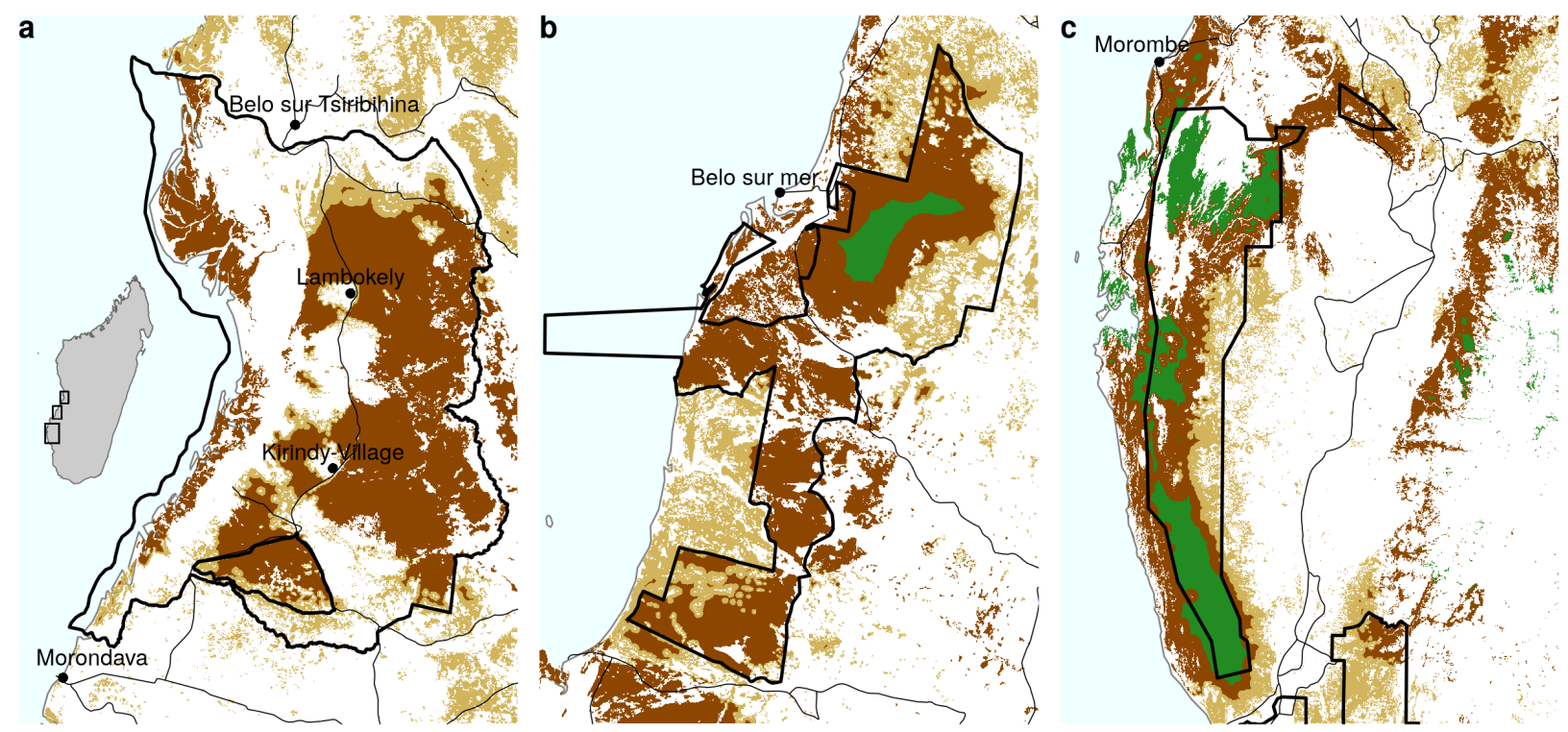

Figure 4: Projected deforestation on the period 2010-2050. Green: projected forest cover in 2050, light brown: 2010-2050 deforestation following conservative scenario S1 (projecting 2000-2010 mean annual deforestation), dark brown: 2010-2050 additional deforestation following scenario S2 (projecting 2010-2017 mean annual deforestation). Most of the 2010-2017 deforestation observed on Fig. 2 is included in the 2010-2050 projections. We predicted a loss of $38-93 \%$ of the forest cover in 2050 compared to 2000 following scenario S1 and S2, respectively. Remaining forest in 2050 under scenario S1 should be concentrated inside protected areas. We predicted a complete loss of the forest for the MANAP study area following scenario S2. 


\section{Appendices}

\subsection{Appendix 1: Spatial probability of deforestation.}
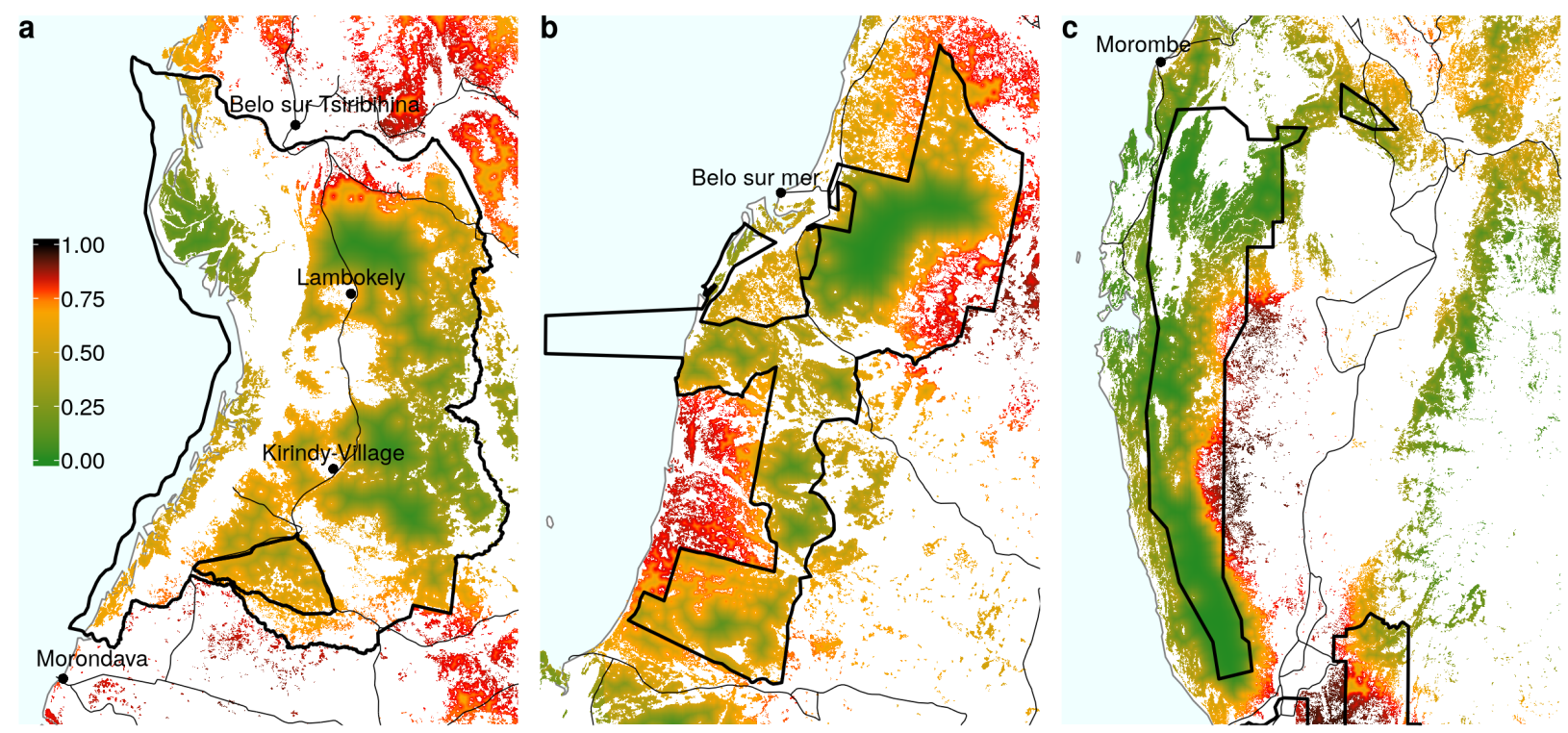

Figure A1: Spatial probability of deforestation for the year 2010. Source: https: /bioscenemada.cirad.fr/forestmaps. The spatial probability of deforestation is modelled as a function of the altitude, the distance to forest edge, the distance to main town, the distance to main road, the protected areas, and the distance to past deforestation. These variables describe the accessibility, the land policy and the historical deforestation. The deforestation model also includes spatial random effects at the regional scale to account for the residual variability in the deforestation process which is not explained by the environmental variables (see https://ghislainv.github.io/forestatrisk for more details on model specifications). 


\subsection{Appendix 2: Fanele and Haruna cyclones.}

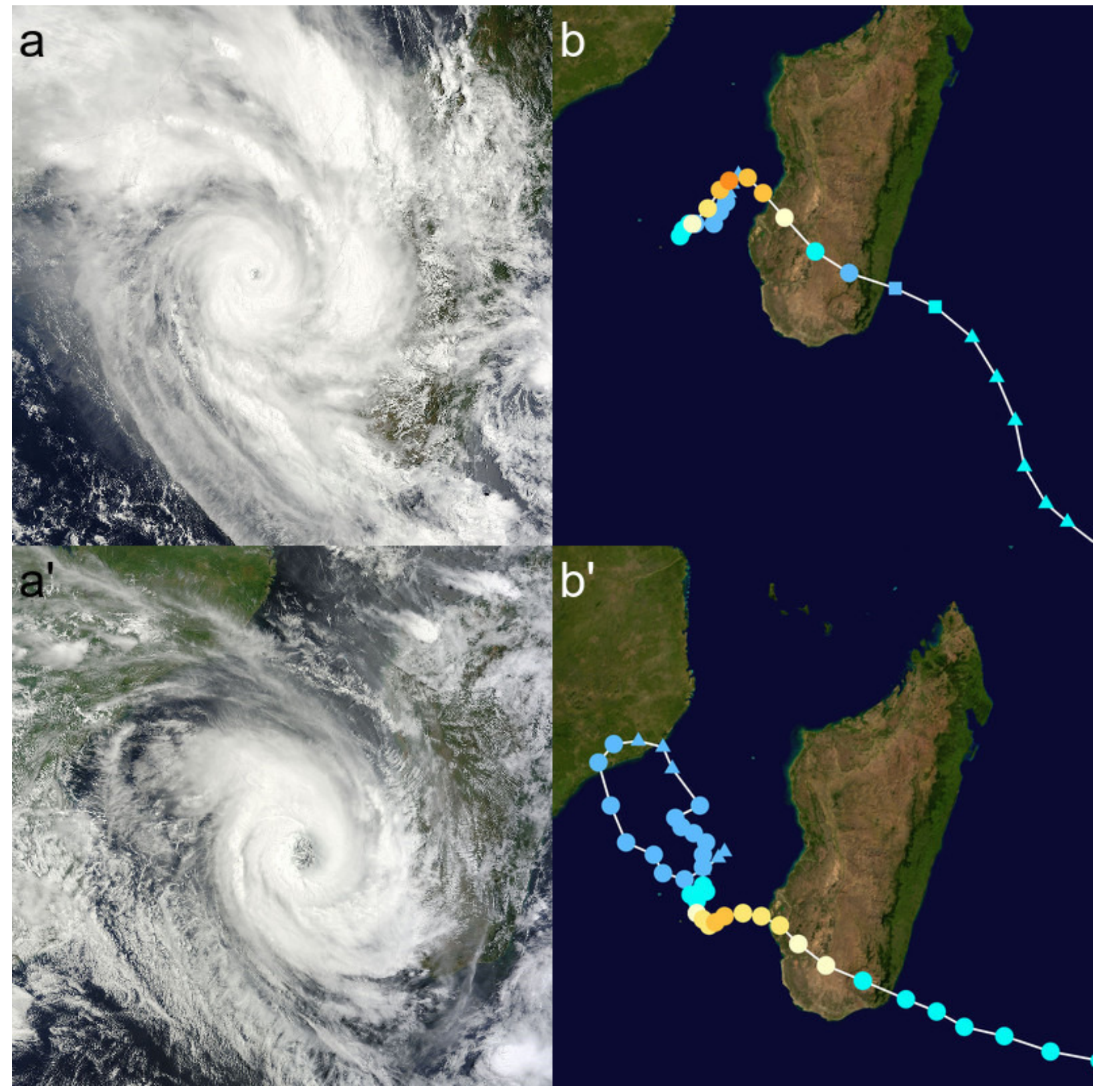

Figure A2: Satellite images and trajectories of cyclones Fanele and Haruna over Madagascar. a-b: Cyclone Fanele in January 2009. a'-b': Cyclone Haruna in February 2013. a-a': MODIS satellite image of the cyclone near peak intensity. b-b': Track and intensity of the cyclone, according to the Saffir-Simpson scale. Highest winds for Fanele: $10-$ min sustained $=185 \mathrm{~km} / \mathrm{h}, 1-$ min sustained $=215 \mathrm{~km} / \mathrm{h}$, gusts $=260 \mathrm{~km} / \mathrm{h}$. Highest winds for Haruna: $10-$ min sustained $=150 \mathrm{~km} / \mathrm{h}, 1-$ min sustained $=195 \mathrm{~km} / \mathrm{h}$, gusts $=$ not available. Source: Wikipedia, https://en.wikipedia.org/wiki/Cyclone_Fanele, https: //en.wikipedia.org/wiki/Cyclone_Haruna. 


\subsection{Appendix 3: Change in maize and peanut exports.}

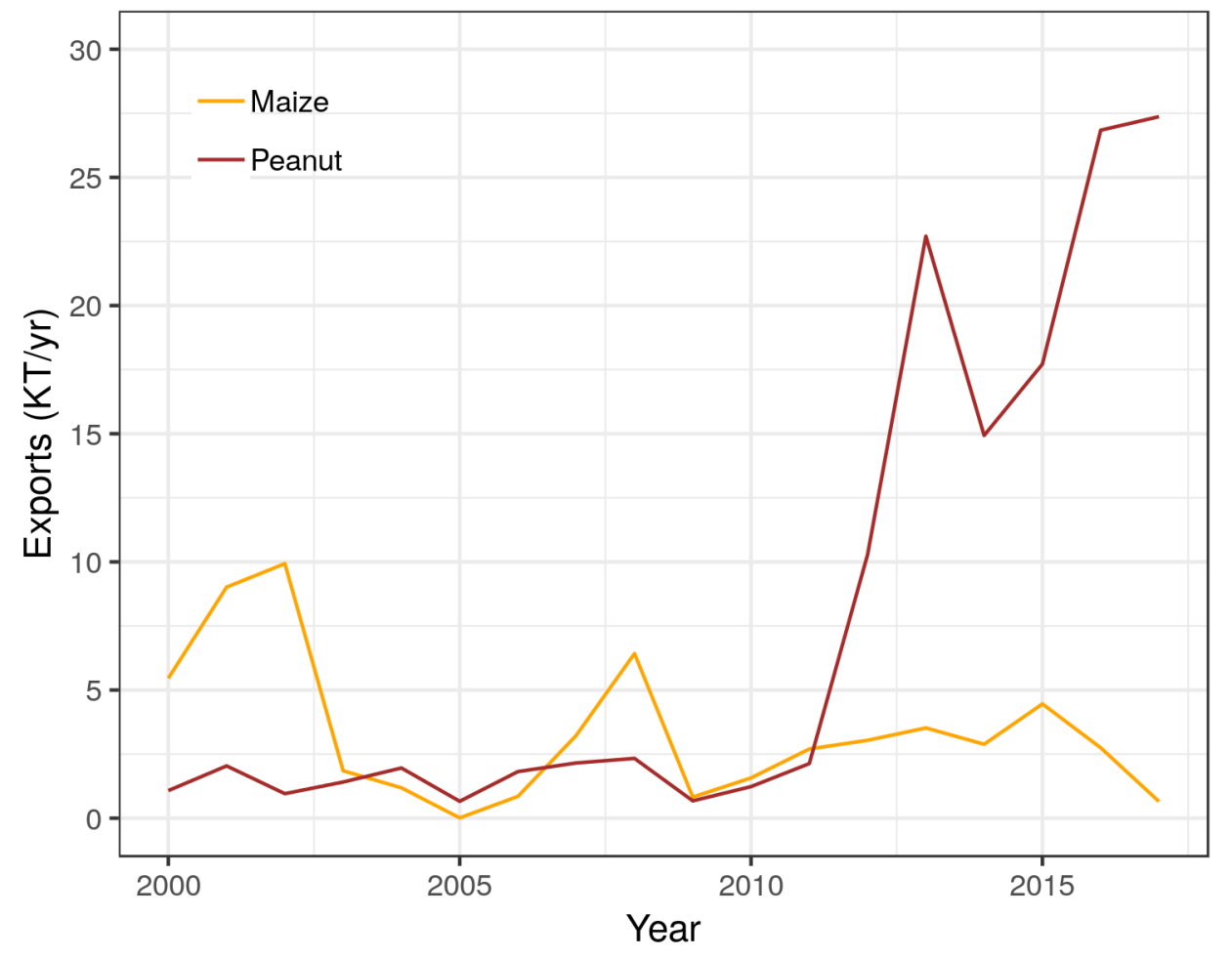

Figure A3: Annual exports in the period 2000-2017 for maize and peanut crops. Exports are reported at the national level for Madagascar in $\mathrm{KT} / \mathrm{yr}$. While maize exports are stable around $5 \mathrm{KT} / \mathrm{yr}$ in the period 2000-2017, peanut exports have boomed since 2011, with about $2.5 \mathrm{KT}$ exported in 2011 to about 27,500 KT in 2017. Sources: UN Comtrade (https://comtrade.un.org). 


\subsection{Appendix 4: Maize and beer consumption in Madagascar.}

Three Horses Beer (better known locally as THB) has been brewed by Star Breweries of Madagascar since 1958. It is the highest selling beer in Madagascar and has been described as emblematic of the country. THB is sold nationwide and since 2005 has been exported to such markets as France, Reunion Island, Comoros and Mayotte. THB Pilsener, the most common variant of THB, is produced from mostly local barley, corn and hops. The mash is a blend of malt (sprouted barley) and corn in an 80/20 ratio to which water and hops are added. In 2006, the Star Brewery was producing 700,000 hectoliters (hL) of beer annually. Star Breweries invested over four million euros into improving its factories in the 2009-2011 period, resulting in a 20\% increase in production capacity (source: Wikipedia, https://en.wikipedia.org/wiki/Three_Horses_Beer). As a consequence, we can assume that about 840,000 hL of THB Pilsener have been produced each year since 2011.

We assumed that about $1.25 \mathrm{~kg}$ of grain is needed to produce $1 \mathrm{~kg}$ of malt, and about $20 \mathrm{~kg}$ of malt are needed to produce $1 \mathrm{hL}$ of beer (Kreisz, 2009). For a total of 840,000 hL of beer, $1.25 \times 20 \times 840,000 / 1000=21,000$ tonnes $(\mathrm{T})$ of grain are needed. Because the mash for the THB Pilsener is a blend of malt and corn in an 80/20 ratio, about 4,200 $\mathrm{T}$ of maize grain are necessary to produce the annual $840,000 \mathrm{hL}$ of beer.

Given the 2010-2017 average yield of 1.7 T/ha for maize crop in Madagascar (Tab. 3), about 2,471 ha of maize crop are necessary to produce the local beer. This number is very small compared to the 225,084 ha of maize harvested at the national level (Tab. 3). 


\section{References}

Allnutt, T.F., Ferrier, S., Manion, G., Powell, G.V.N., Ricketts, T.H., Fisher, B.L., Harper, G.J., Irwin, M.E., Kremen, C., Labat, J.N., Lees, D.C., Pearce, T.A. \& Rakotondrainibe, F. (2008) A method for quantifying biodiversity loss and its application to a 50-year record of deforestation across Madagascar. Conservation Letters, 1, 173-181. ISSN 1755-263X. URL http://dx.doi.org/10.1111/j.1755-263X.2008.00027.x

Anderson, J., Benjamin, C., Campbell, B. \& Tiveau, D. (2006) Forests, poverty and equity in Africa: new perspectives on policy and practice. International Forestry Review, 8, 44-53.

Boucher, D., Roquemore, S. \& Fitzhugh, E. (2013) Brazil's success in reducing deforestation. Tropical Conservation Science, 6, 426-445.

Brooks, T.M., Mittermeier, R.A., da Fonseca, G.A.B., Gerlach, J., Hoffmann, M., Lamoreux, J.F., Mittermeier, C.G., Pilgrim, J.D. \& Rodrigues, A.S.L. (2006) Global Biodiversity Conservation Priorities. Science, 313, 58-61. ISSN 0036-8075.

URL http://science.sciencemag.org/content/313/5783/58

Burns, S.J., Godfrey, L.R., Faina, P., McGee, D., Hardt, B., Ranivoharimanana, L. \& Randrianasy, J. (2016) Rapid human-induced landscape transformation in Madagascar at the end of the first millennium of the Common Era. Quaternary Science Reviews, 134, 92 - 99. ISSN 0277-3791.

URL http://www.sciencedirect.com/science/article/pii/S0277379116300099

Casse, T., Milhøj, A., Ranaivoson, S. \& Randriamanarivo, J.R. (2004) Causes of deforestation in southwestern Madagascar: what do we know? Forest Policy and Economics, 6, 33-48.

Chan Mouie, J.A. (2016) Filière arachides : Les Chinois très demandeurs de la production malgache. Midi Madagascar.

URL http://www.midi-madagasikara.mg/economie/2016/07/29/filiere-arachides-chinoistres-demandeurs-de-production-malgache/

Corson, C. (2014) Conservation politics in Madagascar. The expansion of protected areas. Conservation and Environmental Management in Madagascar. IR Scales (ed.), pp. 193-215.

Costanza, R., d'Arge, R., de Groot, R., Farber, S., Grasso, M., Hannon, B., Limburg, K., Naeem, S., O’Neill, R.V., Paruelo, J., Raskin, R.G., Sutton, P. \& van den Belt, M. (1997) The value of the world's ecosystem services and natural capital. Nature, 387, 253-260.

URL http://dx.doi.org/10.1038/387253a0

Critical Ecosystem Partnership Fund (2014) Ecosystem profile, Madagascar and Indian Ocean islands. Conservation International, Antananarivo, Madagascar.

Demaze, M.T. (2014) L'enrôlement de Madagascar dans la REDD+: domestiquer une opportunité internationale. VertigO-la revue électronique en sciences de l'environnement, 14.

Ebeling, J. \& Yasue, M. (2008) Generating carbon finance through avoided deforestation and 
its potential to create climatic, conservation and human development benefits. Philosophical Transactions of the Royal Society B-biological Sciences, 363, 1917-1924.

Falola, T.O. \& Jean-Jacques, D. (2015) Africa: An Encyclopedia of Culture and Society [3 volumes]. ABC-CLIO. ISBN 9781598846669.

URL https://books.google.it/books?id=YjoVCwAAQBAJ

Fauroux, S. (2000) Instabilité des cours du maïs et incertitude en milieu rural: le cas de la déforestation dans la région de Tuléar (Madagascar). Revue Tiers Monde, pp. 815-839.

Freudenberger, K. (2010) Paradise Lost? Lessons from 25 years of USAID environment programs in Madagascar. International Resources Group, Washington DC.

Gardner, C.J. \& Davies, Z.G. (2014) Rural bushmeat consumption within multiple-use protected areas: qualitative evidence from southwest Madagascar. Human Ecology, 42, $21-34$.

Gardner, C.J., Nicoll, M.E., Mbohoahy, T., Oleson, K.L.L., Ratsifandrihamanana, A.N., Ratsirarson, J., René de Roland, L.A., Virah-Sawmy, M., Zafindrasilivonona, B. \& Davies, Z.G. (2013) Protected areas for conservation and poverty alleviation: experiences from Madagascar. Journal of Applied Ecology, 50, 1289-1294. ISSN 1365-2664.

URL http://dx.doi.org/10.1111/1365-2664.12164

Goodman, S.M. \& Benstead, J.P. (2005) Updated estimates of biotic diversity and endemism for Madagascar. Oryx, 39, 73-77.

Grandin, B.E. et al. (1988) Wealth ranking in smallholder communities: a field manual. Intermediate Technology Publications.

Green, G.M. \& Sussman, R.W. (1990) Deforestation History of the Eastern Rain Forests of Madagascar from Satellite Images. Science, 248, 212-215. ISSN 0036-8075.

URL http://science.sciencemag.org/content/248/4952/212

Hansen, M.C., Potapov, P.V., Moore, R., Hancher, M., Turubanova, S.A., Tyukavina, A., Thau, D., Stehman, S.V., Goetz, S.J., Loveland, T.R., Kommareddy, A., Egorov, A., Chini, L., Justice, C.O. \& Townshend, J.R.G. (2013) High-Resolution Global Maps of 21st-Century Forest Cover Change. Science, 342, 850-853.

URL http://www.sciencemag.org/content/342/6160/850.abstract

Harper, G.J., Steininger, M.K., Tucker, C.J., Juhn, D. \& Hawkins, F. (2007) Fifty years of deforestation and forest fragmentation in Madagascar. Environmental Conservation, 34, $325-333$.

Hobbs, J.J. (2016) Fundamentals of world regional geography. Cengage Learning.

Humbert, H. (1955) Les territoires phytogéographiques de Madagascar. Leur cartographie. Année biologique, 31, 439-448.

Jarosz, L. (1993) Defining and Explaining Tropical Deforestation: Shifting Cultivation and Population Growth in Colonial Madagascar (1896-1940). Economic Geography, 69, 366-379. 
PMID: 12318844.

URL http://www.tandfonline.com/doi/abs/10.2307/143595

Jeannoda, V.H., Razanamparany, J.L., Rajaonah, M.T., Monneuse, M.O., Hladik, A. \& Hladik, C.M. (2007) Les ignames (Dioscorea spp.) de Madagascar: espèces endémiques et formes introduites; diversité, perception, valeur nutritionnelle et systèmes de gestion durable. Revue d'Ecologie, Terre et Vie, 62, 191-207.

Jones, J.P.G., Ratsimbazafy, J., Ratsifandrihamanana, A.N., Watson, J.E.M., Andrianandrasana, H.T., Cabeza, M., Cinner, J.E., Goodman, S.M., Hawkins, F., Mittermeier, R.A., Rabearisoa, A.L., Rakotonarivo, O.S., Razafimanahaka, J.H., Razafimpahanana, A.R., Wilmé, L. \& Wright, P.C. (2019) Last chance for Madagascar's biodiversity. Nature Sustainability, 2, 350-352. ISSN 2398-9629.

URL https://doi.org/10.1038/s41893-019-0288-0

Kiker, C.F. \& Putz, F.E. (1997) Ecological certification of forest products: Economic challenges. Ecological Economics, 20, 37 - 51. ISSN 0921-8009.

URL http://www.sciencedirect.com/science/article/pii/S0921800996000766

Kreisz, S. (2009) Malting, chap. 6, pp. 147-164. John Wiley \& Sons, Ltd. ISBN 9783527623488. URL https://onlinelibrary.wiley.com/doi/abs/10.1002/9783527623488.ch6

Kremen, C., Cameron, A., Moilanen, A., Phillips, S.J., Thomas, C.D., Beentje, H., Dransfield, J., Fisher, B.L., Glaw, F., Good, T.C., Harper, G.J., Hijmans, R.J., Lees, D.C., Louis, E., Nussbaum, R.A., Raxworthy, C.J., Razafimpahanana, A., Schatz, G.E., Vences, M., Vieites, D.R., Wright, P.C. \& Zjhra, M.L. (2008) Aligning Conservation Priorities Across Taxa in Madagascar with High-Resolution Planning Tools. Science, 320, 222-226. ISSN 0036-8075.

URL http://science.sciencemag.org/content/320/5873/222

Laurance, W.F., Koh, L.P., Butler, R., Sodhi, N.S., Bradshaw, C.J.A., Neidel, J.D., Consunji, H. \& Mateo Vega, J. (2010) Improving the Performance of the Roundtable on Sustainable Palm Oil for Nature Conservation. Conservation Biology, 24, 377-381. ISSN 1523-1739. URL http://dx.doi.org/10.1111/j.1523-1739.2010.01448.x

Maxwell, S., Fuller, R., Brooks, T. \& Watson, J. (2016) Biodiversity: The ravages of guns, nets and bulldozers. Nature, 536, 143.

Miller, D.C., Agrawal, A. \& Roberts, J.T. (2013) Biodiversity, Governance, and the Allocation of International Aid for Conservation. Conservation Letters, 6, 12-20. ISSN 1755-263X. URL 10.1111/j.1755-263X.2012.00270.x

Ministère de l'Agriculture, de l'Elevage et de la Pêche de Madagascar (2004) Filières de l'Agriculture, de l'Elevage et de la Pêche, et Actions du Ministère de l'Agriculture, de l'Elevage et de la Pêche: la filière maïs et la filière oléagineux, fiches nº108 et 109 .

URL https://www.inter-reseaux.org/IMG/pdf_108_Filiere_Mais.pdf

Nepstad, D., Soares-Filho, B.S., Merry, F., Lima, A., Moutinho, P., Carter, J., Bowman, M., Cattaneo, A., Rodrigues, H., Schwartzman, S., McGrath, D.G., Stickler, C.M., Lubowski, R., Piris-Cabezas, P., Rivero, S., Alencar, A., Almeida, O. \& Stella, O. (2009) The End of 
Deforestation in the Brazilian Amazon. Science, 326, 1350-1351. ISSN 0036-8075.

URL http://science.sciencemag.org/content/326/5958/1350

Ploch, L. \& Cook, N. (2012) Madagascar's Political Crisis.

Puyravaud, J.P. (2003) Standardizing the calculation of the annual rate of deforestation. Forest Ecology and Management, 177, 593-596.

Réau, B. (2002) Burning for zebu: the complexity of deforestation issues in western Madagascar. Norsk Geografisk Tidsskrift, 56, 219-229.

Scales, I.R. (2011) Farming at the Forest Frontier: Land Use and Landscape Change in Western Madagascar, 1896-2005. Environment and History, 17, 499-524.

Smith, R.J., Muir, R.D.J., Walpole, M.J., Balmford, A. \& Leader-Williams, N. (2003) Governance and the loss of biodiversity. Nature, 426, 67-70. ISSN 0028-0836.

the Fund for Peace (2016) The Failed States Index 2016. Foreign Policy.

United Nations (2017) World Population Prospects: The 2017 Revision. Revision, custom data acquired via website. United Nations, Department of Economic and Social Affairs, Population Division.

URL https://population.un.org/wpp/

Venter, O., Sanderson, E.W., Magrach, A., Allan, J.R., Beher, J., Jones, K.R., Possingham, H.P., Laurance, W.F., Wood, P., Fekete, B.M., Levy, M.A. \& Watson, J.E.M. (2016) Sixteen years of change in the global terrestrial human footprint and implications for biodiversity conservation. Nature Communications, 7, 12558.

Vieilledent, G., Gardi, O., Grinand, C., Burren, C., Andriamanjato, M., Camara, C., Gardner, C.J., Glass, L., Rasolohery, A., Rakoto Ratsimba, H., Gond, V. \& Rakotoarijaona, J.R. (2016) Bioclimatic envelope models predict a decrease in tropical forest carbon stocks with climate change in Madagascar. Journal of Ecology, 104, 703-715. ISSN 1365-2745.

URL http://dx.doi.org/10.1111/1365-2745.12548

Vieilledent, G., Grinand, C., Rakotomalala, F.A., Ranaivosoa, R., Rakotoarijaona, J.R., Allnutt, T.F. \& Achard, F. (2018a) Output data from: Combining global tree cover loss data with historical national forest-cover maps to look at six decades of deforestation and forest fragmentation in Madagascar.

URL http://dx.doi.org/10.18167/DVN1/AUBRRC

Vieilledent, G., Grinand, C., Rakotomalala, F.A., Ranaivosoa, R., Rakotoarijaona, J.R., Allnutt, T.F. \& Achard, F. (2018b) Combining global tree cover loss data with historical national forest cover maps to look at six decades of deforestation and forest fragmentation in Madagascar. Biological Conservation, 222, 189-197.

URL https://doi.org/10.1016/j.biocon.2018.04.008

Vieilledent, G., Grinand, C. \& Vaudry, R. (2013) Forecasting deforestation and carbon emissions in tropical developing countries facing demographic expansion: a case study in Madagascar. Ecology and Evolution, 3, 1702-1716. ISSN 2045-7758.

URL http://dx.doi.org/10.1002/ece3.550 
Virah-Sawmy, M., Gardner, C. \& Ratsifandrihamanana, A. (2014) The Durban Vision in practice: Experiences in the participatory governance of Madagascar's new protected areas. Conservation and Environmental Management in Madagascar. I. Scales (ed.), pp. 216-251.

Youssi, S. (2008) L'analyse de la filière arachide dans la région du Sud Ouest malgache : outil d'appui à la réflexion stratégique d'une organisation paysanne régionale. Master's thesis, Montpellier SupAgro - Institut des Régions Chaudes.

URL http://www.museum.agropolis.fr/pages/savoirs/organisations_paysannes/stephanie_ youssi.pdf

Zinner, D., Wygoda, C., Razafimanantsoa, L., Rasoloarison, R., Andrianandrasana, H.T., Ganzhorn, J.U. \& Torkler, F. (2014) Analysis of deforestation patterns in the central Menabe, Madagascar, between 1973 and 2010. Regional Environmental Change, 14, $157-166$. 